\title{
VASCULAR LAND PLANT DIVERSITY IN A BIOGEOGRAPHIC CONTEXT
}

RAYMOND, Anne, Department of Geology, Texas A\&M University, College Station, TX 77843-3115 U.S.A., METZ, Cheryl, Department of Geology, Texas A\&M University, College Station, TX 77843-3115 U.S.A.

The history of vascular land plant diversity from the late Silurian to the Early Carboniferous has two major features: a pronounced diversity peak in the late Siegenian-Emsian (Devonian), approximately 12 million years after the appearance of vascular land plant body fossils; and a diversity low in the late Frasnian-early Famennian (Devonian), which coincides with the Frasnian-Famennian mass extinction of marine invertebrate faunas. Because the diversity of fossil land plants depends in part on sampling intensity, this diversity history requires evaluation. Biogeographic data are useful for assessing diversity histories because they incorporate one of the best measures of sampling intensity, the number of localities known from a time interval, and because the amount of biogeographic differentiation present during an interval may influence global diversity.

The data for this study consist of compression-impression genera from 394 Late

Silurian-Devonian and 64 Tournaisian (Early Carboniferous) floral assemblage lists. Most of these assemblage lists represent florules: defined as the compressionimpression genera found in a single formation, member, or other narrow stratigraphic horizon at a single outcrop. However the data include some regional lists from China and parts of the former U.S.S.R., because we could not obtain florules for all time intervals from these regions. Regional lists consist of the genera found in one formation from a limited geographic region. All of the Laurussian assemblage lists used in this study (244 Late Silurian -Devonian and 49 Tournaisian lists), including those from the Russian platform, represent florules. Linear regression of both the total diversity and the standing diversity of vascular land plant genera against the number of floral assemblage lists from each interval suggests that the number of floral assemblage lists correlates strongly and significantly with generic diversity $(r=0.88)$. Thus, the late Siegenian-Emsian diversity peak is probably an artifact of sampling: there are more florules described from the late Siegenian-Emsian than from the Eifelian and Givetian combined. The late Frasnian - early Famennian diversity low may be an artifact of sampling: few reliably-dated assemblages exist for this interval. However, late Frasnian - early Famennian assemblages show no biogeographic differentiation between 'equatorial' Laurussian assemblages from the United States and Europe and northern 'non-equatorial' assemblages from Arctic Canada and Siberia. This biogeographic differentiation is a persistent feature of floral assemblages from all other Devonian time intervals, and from the Early Carboniferous. Low numbers of florules could cause an apparent loss of biogeographic differentiation for an interval. Conversely, all three phenomena (low diversity, low numbers of florules, and loss of biogeographic differentiation) may indicate that the Frasnian-Famennian mass extinction affected terrestrial land plants.

The diversity history of Late Silurian through Early Carboniferous land plants suggests that three major evolutionary innovations: heterospory, which appeared in the late Emsian; arborescence, which appeared in the Givetian; and seeds, which appeared in the late Famennian had little effect on land plant diversity. 